\title{
Isotopic reconstruction of the African Humid Period and Congo Air Boundary migration at Lake Tana, Ethiopia
}

\author{
Kassandra Costa ${ }^{\mathrm{a}, \mathrm{c}, *}$, James Russell $^{\mathrm{a}, *}$, Bronwen Konecky ${ }^{\mathrm{a}, \mathrm{d}}$, Henry Lamb ${ }^{\mathrm{b}}$ \\ a Department of Geological Sciences, Brown University, Box 1846, Providence, RI 02912, USA \\ ${ }^{\mathrm{b}}$ Institute of Geography and Earth Sciences, University of Wales, Aberystwyth SY23 3DB, UK \\ ${ }^{c}$ Lamont-Doherty Earth Observatory of Columbia University, 61 Route 9W, Palisades, NY 10964, USA \\ ${ }^{\mathrm{d}}$ School of Earth \& Atmospheric Sciences, Georgia Institute of Technology, 311 Ferst Drive, Atlanta, GA 30332-0340, USA
}

\section{A R T I C L E I N F O}

\section{Article history:}

Received 7 June 2013

Received in revised form

9 October 2013

Accepted 28 October 2013

Available online 22 November 2013

\section{Keywords:}

Tropical paleoclimate

East Africa

Compound specific hydrogen isotopes

African Humid Period

Holocene paleoclimate

Air mass trajectories

Congo Air Boundary

\begin{abstract}
A B S T R A C T
The African Humid Period of the early to mid-Holocene (12,000-5000 years ago) had dramatic ecological and societal consequences, including the expansion of vegetation and civilization into the "green Sahara." While the humid period itself is well documented throughout northern and equatorial Africa, mechanisms behind observed regional variability in the timing and magnitude of the humid period remain disputed. This paper presents a new hydrogen isotope record from leaf waxes ( $\left.\delta D_{\text {wax }}\right)$ in a 15,000 -year sediment core from Lake Tana, Ethiopia $\left(12^{\circ} \mathrm{N}, 37^{\circ} \mathrm{E}\right)$ to provide insight into the timing, duration, and intensity of the African Humid Period over northeastern Africa. $\delta D_{\text {wax }}$ at Lake Tana ranges between $-80 \%$ and $-170 \%$, with an abrupt transition from D-enriched to D-depleted waxes between 13,000 $-11,500$ years before present $(13-11.5 \mathrm{ka})$. A similarly abrupt transition from D-depleted to D-enriched waxes occurs ca $8.5-8 \mathrm{ka}$ and is followed by generally D-enriched waxes throughout the late Holocene. Trends in $\delta D_{\text {wax }}$ covary with changes in Northern Hemisphere summer insolation and reflect increased precipitation at Lake Tana during the AHP; however, the transition from D-depleted to D-enriched waxes occurs earlier at Lake Tana (ca $8 \mathrm{ka}$, vs $5 \mathrm{ka}$ ) than in many other regional records, and the amplitude of Ddepletion during the AHP is larger at Lake Tana as well. We attribute this early enrichment to a reduction of moisture derived from westerly sources (the Congo Basin and Atlantic Ocean) which we suggest are Ddepleted relative to moisture sourced from the east (Indian Ocean) and the north (Red Sea and Mediterranean Sea). Our new record highlights the importance of both the northward migration of the tropical rain belt as well as east-west migration of the Congo Air Boundary to precipitation source and amount during the African Humid Period.
\end{abstract}

(c) 2013 Elsevier Ltd. All rights reserved.

\section{Introduction}

The climate of Intertropical Africa is governed by changes in the strength and position of the tropical rain belt, related to the InterTropical Convergence Zone (ITCZ). The tropical rain belt migrates at seasonal to orbital time-scales in response to variations in the interhemispheric temperature gradient (Broccoli et al., 2006). Eleven thousand years before present (11 ka), when Northern Hemisphere summer insolation was at a maximum, the mean position of the tropical rain belt shifted to the north, generating increased rainfall across much of Northern Africa (Gasse, 2000). Increased precipitation and the northward expansion of vegetation

\footnotetext{
* Corresponding authors. Department of Geological Sciences, Brown University Box 1846, Providence, RI 02912, USA.

E-mail addresses: kcosta@Ideo.columbia.edu (K. Costa), James_Russell@brown. edu (J. Russell).
}

zones during the African Humid Period (AHP, ca $12-5 \mathrm{ka}$ ) allowed ancient civilizations in North Africa to thrive, and the subsequent return to arid-semiarid climate has been invoked to explain major societal shifts, including the collapse of the Egyptian Old Kingdom (Brooks et al., 2005; Kuper and Kröpelin, 2006). The early Holocene shift to humid conditions was particularly extreme in North Africa (deMenocal et al., 2000; Gasse, 2000; Chalie and Gasse, 2002; Garcin et al., 2012), but it has also been observed in the tropical Americas (Haug et al., 2001), Asia (Wang et al., 2001; Dykoski et al., 2005), and the Middle East (Fleitmann et al., 2007).

While there is strong evidence for an orbitally-forced African Humid Period, the spatial and temporal patterns of AHP onset, intensity, and termination are highly debated. The transition into and out of the AHP has been alternately described as synchronous and abrupt (deMenocal et al., 2000; Adkins et al., 2006; Shanahan et al., 2006; Tierney et al., 2008) and asynchronous and gradual (Jung et al., 2004; Kröpelin et al., 2008; Chase et al., 2009; Niedermeyer 


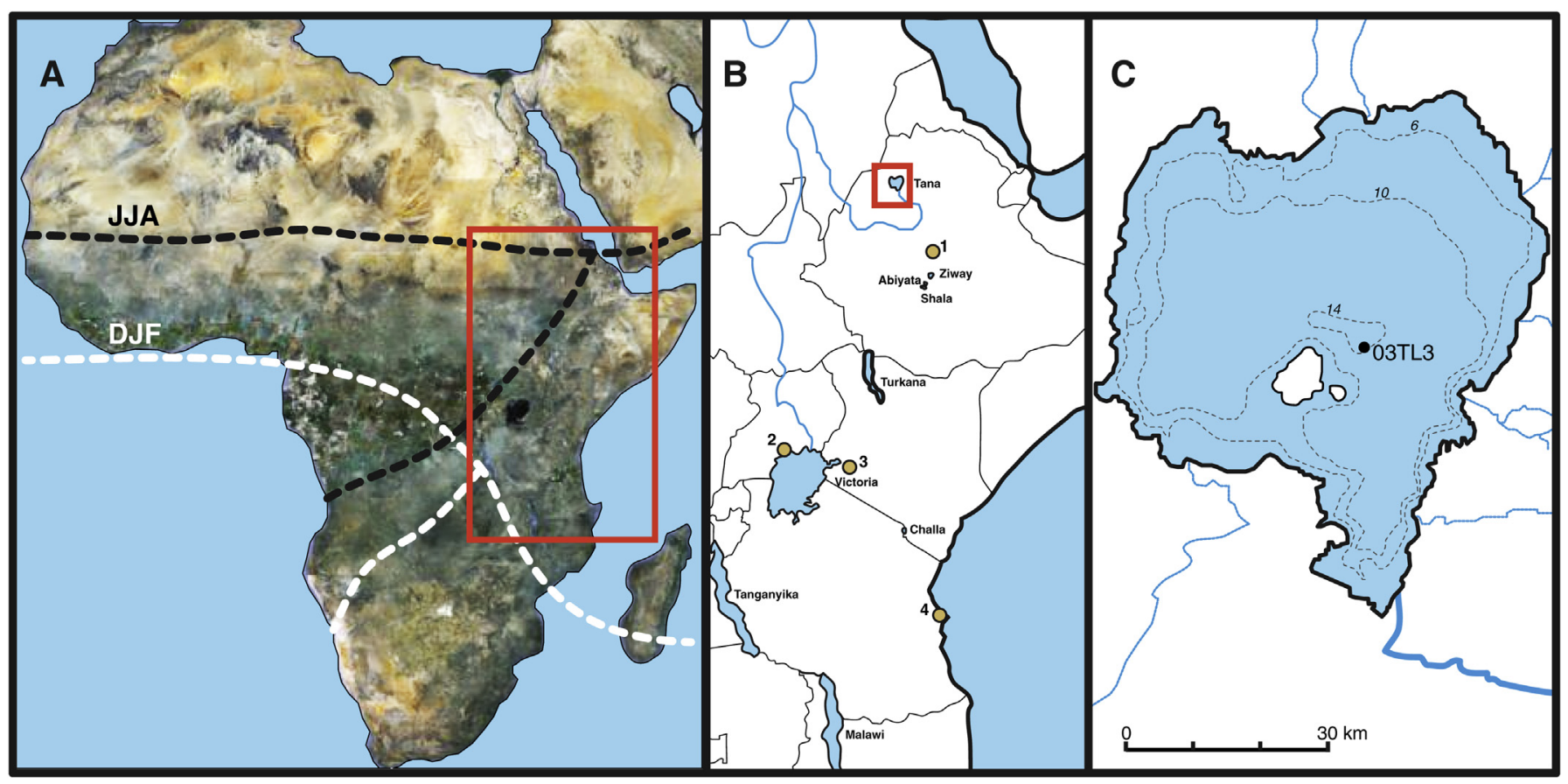

Fig. 1. A) Map of Africa illustrating the northern (JJA, black dashed lines) and southern (DJF, white dashed lines) limits of the tropical rain belt and the Congo Air Boundary (Nicholson, 1993; Tierney et al., 2011a). The red box denotes the East African lakes region. B) Magnification of the East African lakes region. Lake Tana sources the Blue Nile, which joins with White Nile, sourced from Lake Victoria, to form the Nile proper. The red box denotes Lake Tana. Numbered yellow circles indicate Global Network of Isotopes in Precipitation (GNIP) stations: 1. Addis Ababa, Ethiopia 2. Entebbe, Uganda 3. Kericho, Kenya 4. Dar es Salaam, Tanzania. C) Map of Lake Tana, showing the lake bathymetry and the location of core 03TL3. Dotted blue lines indicate river inflow, solid blue line indicates outflow, i.e., the Blue Nile. (For interpretation of the references to colour in this figure legend, the reader is referred to the web version of this article.)

et al., 2010; Marshall et al., 2011). Results from climate models are similarly inconclusive, suggesting, for example, an abrupt transition in West Africa and a gradual one in East Africa (Hély et al., 2009) or an abrupt vegetation collapse followed by gradual precipitation decline (Liu et al., 2007). Abrupt and synchronous changes in North African rainfall have often been attributed to positive feedbacks between vegetation and precipitation (Claussen et al., 1999; deMenocal et al., 2000). However, AHP responses have also been attributed to changes in Indian Ocean sea surface temperatures, feedbacks between the monsoons and coastal upwelling intensity, and migration not only of the tropical rain belt, but also the Congo Air Boundary (CAB), the convergence zone over Central Africa that separates Atlantic and Indian Ocean air masses (Liu et al., 2003; Adkins, 2006; Tierney et al., 2008). Understanding the rate and synchroneity of the onset and termination of the AHP is important to identifying the underlying atmospheric circulation patterns and feedbacks that respond to and amplify orbitally-forced changes in the tropical rain belt, with potential significance for climate changes in the future.

Existing proxy reconstructions exhibit significant differences in the timing of the onset and, more particularly, the termination of the AHP over northern and eastern Africa. While these differences could indicate real gradients in the early to mid-Holocene hydroclimate of tropical Africa, they could also arise from the use of very different proxies (e.g., dust flux, lake salinity, vegetation), which have different inherent sensitivities, threshold effects, and possible lags when used to reconstruct surface moisture balance. The emergence of compound-specific hydrogen isotope $(\delta D)$ records of African hydroclimate could help mitigate these inter-proxy inconsistencies (Tierney et al., 2008, 2011b; Konecky et al., 2011; Schefuss et al., 2011; Berke et al., 2012). This is because $\delta D$ primarily records large-scale atmospheric processes such as precipitation, circulation, and convection. This paper presents a new compound-specific hydrogen isotope record from Lake Tana, Ethiopia to provide insight into how the migration of the tropical rain belt and the $C A B$ impacts on the timing, duration, and intensity of the AHP over northeastern Africa.

\section{Site information, materials, and methods}

Lake Tana $\left(12^{\circ} \mathrm{N}, 37.25^{\circ} \mathrm{E}, 1830\right.$ m elevation) is Ethiopia's largest lake, containing $50 \%$ of the country's freshwater resources (Fig. 1) (Lamb et al., 2007; Vijverberg et al., 2009). Four permanent rivers supply $95 \%$ of the lake's inflow. Hydrologic balance is maintained mainly through evaporation (64\% of water loss) and outflow via the Blue Nile (Vijverberg et al., 2009). The lake is surrounded by dry montane forest as well as permanent and seasonal wetlands that are predominantly populated by Cyperus papyrus, Typha latifolia, Phragmites karka, Persicaria senegalensis, Vossia spp., Scirpus spp., and Nymphaea lotus (Vijverberg et al., 2009). The average annual precipitation at Lake Tana is $1410 \mathrm{~mm}$ (Lamb et al., 2007). Precipitation occurs almost entirely during the May-October rainy season (Vijverberg et al., 2009), when the tropical rain belt is at its northern limit and the CAB is at its eastern limit (Nicholson, 2000).

The modern isotopic composition of Ethiopian precipitation is anomalously enriched relative to other East African locations: the mean annual hydrogen isotope composition of rainfall ( $\left.\delta D_{\text {precip }}\right)$ at Addis Ababa is $1.8 \%$, compared to $-11.2 \%$ at Entebbe, Uganda, $-16.3 \%$ at Kericho, Kenya, and $-13.3 \%$ at Dar es Salaam, Tanzania (Rozanski et al., 1993; Levin et al., 2009). Previous work has debated the causes of this isotopically enriched precipitation, and in particular the relative influence of moisture sources derived from the Indian Ocean versus the Congo Basin and Atlantic Ocean. Some authors have attributed the D-enrichment of precipitation to the incursion of D-enriched vapor derived from the Atlantic Ocean and recycled over the central African rainforests during June-August 
(Rozanski et al., 1993; Levin et al., 2009), while others have suggested that it is derived from the first condensation of Indian Ocean-derived vapor carried by the easterly jets (Joseph et al., 1992).

The hydrogen isotope composition of terrestrial leaf wax compounds $\left(\delta D_{\text {wax }}\right)$ was analyzed in piston core $03 T L 3$, which was taken from Lake Tana in October 2003 at $13.8 \mathrm{~m}$ water depth near the lake center (Lamb et al., 2007). The age model for this core is based on 17 AMS ${ }^{14} \mathrm{C}$ dates interpolated using a locally weighted mixed effect regression (Marshall et al., 2011). The sampling resolution for $\delta D_{\text {wax }}$ analyses averages about 200-300 years, and lipid extraction, leaf wax purification, and isotopic analysis followed the procedures outlined by Konecky et al. (2011). $\delta D_{\text {wax }}$ was measured on long-chain $n$-alkanoic acids, of which the dominant homologues were the $\mathrm{C}_{26}$ and $\mathrm{C}_{28} n$-acid, both derived primarily from terrestrial plants (Sachse et al., 2004). Samples were measured in duplicate and triplicate using a gas chromatograph (GC) and a Delta XL isotope ratio mass spectrometer (IRMS) at Brown University and are reported relative to VSMOW. For $\mathrm{C}_{28} n$-acid, the standard deviation for sample triplicates ( 5 of 59 samples) averaged $2.25 \%$, and the difference for sample duplicates averaged $1.56 \%$, with a maximum difference of $5.60 \%$. All $\delta D$ data are corrected as in Konecky et al. (2011) for the methyl group added during methylation as well as ice volume effects. Carbon isotopes of the leaf waxes $\left(\delta^{13} C_{\text {wax }}\right)$ were run in duplicate on a Thermo Finnegan Delta XL GCIRMS at Brown University and are reported relative to VPDB. For $\mathrm{C}_{28}$ $n$-acid, $\delta^{13} C_{\text {wax }}$ differences averaged $0.165 \%$ with a maximum of $0.435 \%$. All $\delta^{13} \mathrm{C}$ data are corrected for the methyl group added during methylation.

To evaluate the potential of changing vapor sources to affect $\delta D_{\text {precip }}$ at Lake Tana, moisture sources were reanalyzed using air mass trajectories generated by the NOAA Hybrid Single Particle Lagrangian Integrated Trajectory (HYSPLIT) 4 Model (Draxler and Hess, 1998). One-week air mass back-trajectories were calculated using NCEP Reanalysis data at 12-h intervals for 12 full years, 2000-2011, and filtered for only those air masses that rained within 12 hours of reaching Lake Tana. The trajectories were clustered into source regions, which were subsequently assessed for their relative precipitation contributions to the annual mean to provide a site-specific evaluation of moisture sources to Lake Tana.

\section{Results}

$\delta D$ of $C_{26}$ and $C_{28}$ leaf wax homologues at Lake Tana are highly correlated $\left(r^{2}=0.95\right)$ with average values of $-125 \%$ and $-122 \%$, respectively (Fig. 2). Given the strong correlation, we focused our analyses on the most abundant homologue, $C_{28}$; henceforth ' $\delta D_{\text {wax }}$ ' refers to the $\delta D$ of $C_{28} n$-acid. $\delta D_{\text {wax }}$ at Lake Tana ranges between $-80 \%$ and $-170 \%$, with D-enriched waxes from ca 15 to $13.5 \mathrm{ka}, \mathrm{D}$ depleted waxes from 11.5 to $8.5 \mathrm{ka}$, and relatively D-enriched waxes from $\sim 8 \mathrm{ka}$ to the present. The transition from D-enriched to Ddepleted waxes appears abrupt, beginning ca $13 \mathrm{ka}$, reaching a plateau from $\sim 12.7$ to $12 \mathrm{ka}$, and decreasing abruptly between 12 and $11.5 \mathrm{ka}$ to its early Holocene minimum. The waxes remain very D-depleted until $8.5 \mathrm{ka}$, when $\delta D_{\text {wax }}$ abruptly shifts to about $-100 \%$, similar to its late Holocene (5-0 ka) average $(-103 \%$ ). There is a brief D-depletion ca $7 \mathrm{ka}$, after which time the waxes become gradually more $\mathrm{D}$-enriched toward the late Holocene.

$\delta^{13} \mathrm{C}$ of $\mathrm{C}_{26}$ and $\mathrm{C}_{28}$ leaf wax homologues at Lake Tana are correlated $\left(r^{2}=0.70\right)$ with average values of $-25.0 \%$ and $-26.3 \%$, respectively. Henceforth ' $\delta{ }^{13} C_{\text {wax }}$ ' refers specifically to the $\delta^{13} \mathrm{C}$ of the $C_{28} n$-acid. $\delta^{13} C_{\text {wax }}$ ranges from $-23.4 \%$ to $-30 \%$ with very weak trends from $15 \mathrm{ka}$ to present. $\delta^{13} \mathrm{C}_{\text {wax }}$ is more enriched than typical fatty acids derived from terrestrial plant material of pure $C_{3}$ origin (Chikaraishi and Naraoka, 2007), suggesting the waxes are

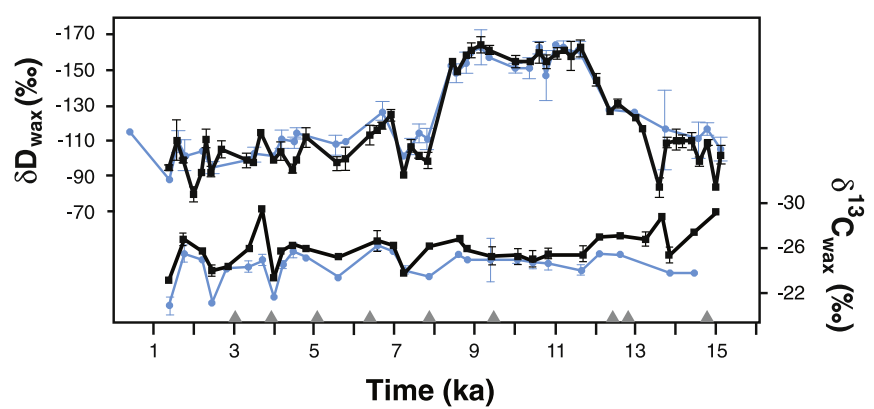

Fig. 2. $\delta D$ and $\delta^{13} C$ for $C_{26}$ (blue) and $C_{28}$ (black) leaf waxes. Gray triangles indicate ${ }^{14} C$ tiepoints in the age model. For $\delta D$ of $C_{28} n$-acid, the standard deviation for sample triplicates ( 5 of 59 samples) averaged $2.25 \%$, and the difference for sample duplicates averaged $1.56 \%$, with a maximum difference of $5.60 \%$. For $C_{28} n$-acid, $\delta^{13} C_{\text {wax }}$ differences averaged $0.165 \%$ with a maximum of $0.435 \%$. Error bars reflect $2 \sigma$ (standard deviation where available, and two times the difference elsewhere), not shown where smaller than the data symbols. (For interpretation of the references to colour in this figure legend, the reader is referred to the web version of this article.)

derived from a mixture of $C_{3}$ and $C_{4}$ plants in accordance with the vegetation observed around the lake (Vijverberg et al., 2009). Changing relative abundance of $C_{3}$ and $C_{4}$ plants may impact the $\delta D_{\text {wax }}$ observed at Lake Tana because the two plant types fractionate hydrogen and deuterium to different extents; waxes of $\mathrm{C}_{4}$ plants are generally $20 \%$ more D-enriched than those of $C_{3}$ plants (Sachse et al., 2012, and references therein). However, assuming endmember $\delta^{13} C_{\text {wax }}$ of $-36.9 \%$ and $-22.0 \%$ for $C_{3}$ and $C_{4}$ respectively, the $6.5 \%{ }^{13} \mathrm{C}_{\mathrm{wax}}$ variation observed at Lake Tana can only cause $\pm 9 \%$ changes in $\delta D_{\text {wax }}$ (Chikaraishi et al., 2004; Smith and Freeman, 2006; Chikaraishi and Naraoka, 2007; Hou et al., 2008). These changes are negligible compared to the $60 \%$ D-depletion observed at Lake Tana during the AHP.

Assuming that changes in biosynthetic fractionation driven by changing vegetation only weakly influence our $\delta D_{\text {wax }}$ record, the $\delta D_{\text {wax }}$ from Lake Tana most directly reflects the deuterium to hydrogen isotopic ratio of precipitation ( $\delta D_{\text {precip }}$ ) (Huang et al., 2004; Sachse et al., 2004; Hou et al., 2008). In the tropics, $\delta D_{\text {precip }}$ is commonly interpreted to record changes in precipitation amount by way of the amount effect (Dansgaard, 1964; Rozanski et al., 1993). However, $\delta D_{\text {precip }}$ reflects more than just local precipitation amount: it integrates the entire atmospheric history of the air mass from which it is derived, including the moisture source region, transport distance, and convective, evaporative, and distillative history (Dansgaard, 1964; Vuille et al., 2005; LeGrande and Schmidt, 2009; Konecky et al., 2011). Changes in air temperature can further distort the $\delta D_{\text {precip }}$ signal (see discussion in, e.g., Konecky et al., 2011), but temperature effects are generally small in the tropics, at least during the Holocene (Rozanski et al., 1993; Vuille et al., 2005). For this paper, it is assumed that fluctuations in $\delta D_{\text {wax }}$ primarily reflect changes in atmospheric circulation and the hydrological cycle.

\section{Discussion}

Long-term trends in $\delta D_{\text {wax }}$ at Lake Tana vary strongly in relation to changes in Northern Hemisphere $(\mathrm{NH})$ summer insolation over the last 15,000 years. The waxes are D-depleted during the interval of maximum summer insolation (centered around $11 \mathrm{ka}$ ) and Denriched during intervals of minimum summer insolation (the glacial termination and late Holocene). Northward migration of the tropical rain belt in response to maximum $\mathrm{NH}$ insolation should have increased annual precipitation at Lake Tana, which, by way of the amount effect, would result in decreased $\delta D_{\text {wax. }}$ This mechanism is supported by the correlation between Lake Tana $\delta D_{\text {wax }}$ and 
paleohydrologic records from numerous other East African lakes, including surface runoff reconstructions from Lake Tana itself (Marshall et al., 2011) and lake level and salinity reconstructions from elsewhere in Ethiopia (Fig. 3; Gillespie et al., 1983; Gasse and Van Campo, 1994; Chalie and Gasse, 2002; Foerster et al., 2012), which suggest maximum regional humidity at $10 \pm 1 \mathrm{ka}$.

While many records, including ours from Lake Tana, suggest increased precipitation during the early to middle Holocene, the local manifestations of the AHP appear highly variable in space and time. This includes the AHP as recorded by an evolving network of $\delta D_{\text {wax }}$ datasets from East African lakes, which now span $16^{\circ} \mathrm{S}$ to $12^{\circ} \mathrm{N}$ and permit investigation of the dynamics of the AHP using a single paleohydrologic proxy. Comparison of these $\delta D_{\text {wax }}$ datasets highlights both the large-scale changes in climate and atmospheric circulation over East Africa during the AHP, as well as regional variability in the timing, amplitude, and rate of change during AHP initiation and termination (Fig. 4). All sites north of Lake Tanganyika $\left(4-9^{\circ} \mathrm{S}\right)$ have D-depleted waxes and inferred wet conditions during the early Holocene. The onset and termination of the AHP appear abrupt at Lakes Tanganyika and Tana, but gradual at Lakes Victoria and Challa (Tierney et al., 2008, 2011b; Berke et al., 2012). The onset

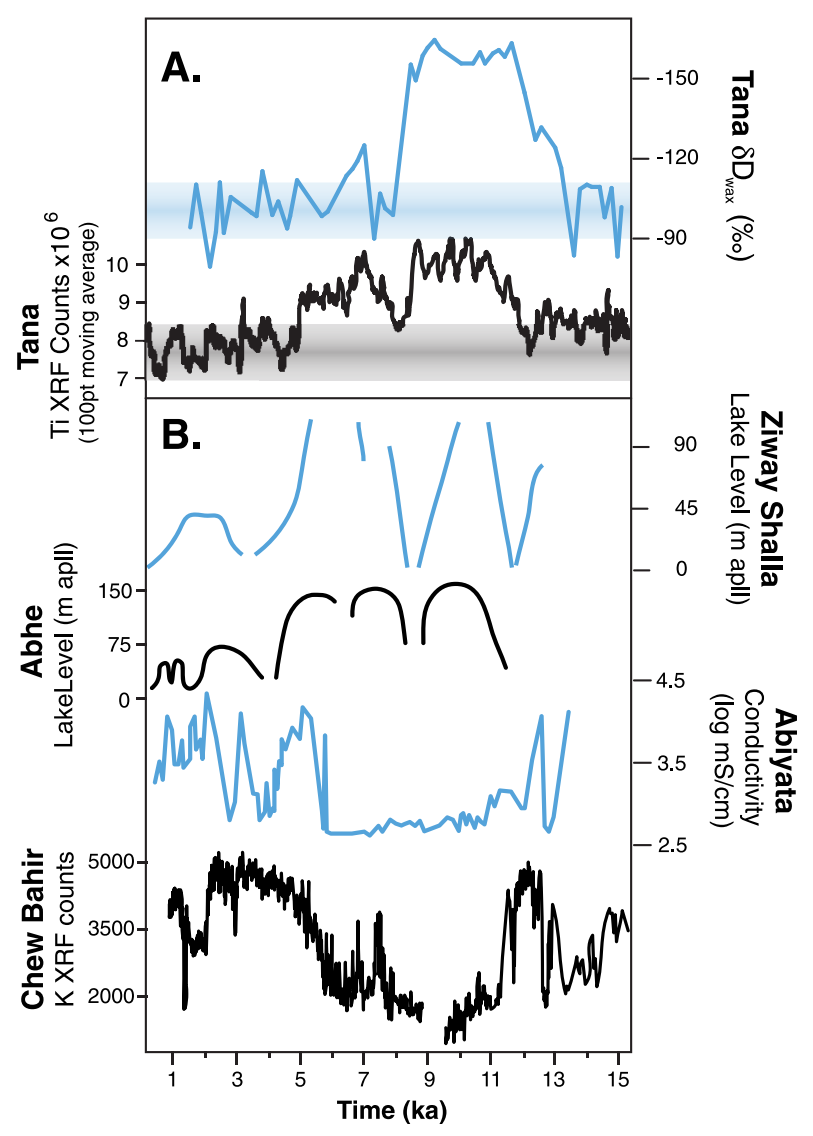

Fig. 3. Paleoclimate records from Ethiopia. A. Lake Tana $\delta D$ of $C_{28}$ leaf wax and titanium XRF counts (Marshall et al., 2011). Shaded regions indicate the Late Holocene (5$0 \mathrm{ka}$ ) average for each proxy (dark line) and $1 \sigma$ variation (shading): $\delta D_{\text {wax }}=-103 \pm 10 \%$, Ti XRF $=7.77 \pm 0.7 \times 10^{6}$ counts. The apparent delay in the onset of humid conditions as inferred from the Ti record is a function of the Younger Dryas signal, which is much stronger in Ti than in $\delta D_{\text {wax. }}$. After the $8.5 \mathrm{ka}$ event, the $\delta D_{\text {wax }}$ varies around the Late Holocene average of $-103 \%$. Titanium, on the other hand, does not reach its Late Holocene average of $7.77 \times 10^{6}$ counts after the 8.5 ka event; it remains elevated (average $\sim 9 \times 10^{6}$ counts) from $8.5-5 \mathrm{ka}$, which is only a marginal decrease from the AHP average of $10 \times 10^{6}$ counts. B. Lake Ziway-Shalla lake level (Gillespie et al., 1983). Lake Abhe lake level reconstruction (Gasse and Van Campo, 1994). Diatom-inferred conductivity at Lake Abiyata (Chalie and Gasse, 2002). Chew Bahir potassium XRF counts (Foerster et al., 2012). of the AHP occurs earliest at Tanganyika $\left(6.5^{\circ} \mathrm{S}\right) \mathrm{ca} 15 \mathrm{ka}$, similar in timing to the transition to decreased $\delta D$ values in $n$-alkanes observed off NW Africa (Niedermeyer et al., 2010). This timing leads the initiation of the AHP at Tana $\left(12^{\circ} \mathrm{N}\right)$ at $13 \mathrm{ka}$, while onset at Challa $\left(3.3^{\circ} \mathrm{S}\right)$ is ambiguous due to the high amplitude of millennial scale variability in the record (Tierney et al., 2011b). The termination of the AHP at Tanganyika also lags the termination at Tana, while both Victoria and Challa show gradual isotopic enrichment from the early to middle Holocene. Despite these differences, Tana, Victoria, and Challa all show the greatest D-depletion between $\sim 11.5$ and $8.5 \mathrm{ka}$, when Tanganyika also shows very D-depleted waxes. All of these $\delta D_{\text {wax }}$ records are dated via AMS ${ }^{14} \mathrm{C}$ ages $(n \geq 17$ samples per core), and standard errors on age models (on the order of several 100 years in the Holocene) are unlikely to obviate the differences in timing observed in the records (on the order of 1000 years). Additionally, rapid sediment accumulation rates, often coupled with bottom-water anoxia, suggest that the influence of bioturbation is minimal. Thus, these data suggest peak intensity of the AHP over East Africa between $\sim 11.5$ and $8.5 \mathrm{ka}$, but with a variable duration of the AHP and a variable rate of its onset and termination.

Lake Malawi $\left(9-14^{\circ} \mathrm{S}\right)$ lies at or near the "hinge zone" that separates sites with a 'northern mode' of orbital-scale climate variability from those with a 'southern mode' (Barker and Gasse, 2003), and shows weak orbital-scale signals in $\delta D_{\text {wax }}$ over the last $21 \mathrm{ka}$ (Konecky et al., 2011). In contrast, $\delta D_{\text {wax }}$ from the Zambezi Fan $\left(16^{\circ} \mathrm{S}\right)$, south of Lake Malawi, generally tracks Southern Hemisphere summer insolation (Schefuss et al., 2011). Peak D-enrichment of waxes occurs ca $9 \mathrm{ka}$, followed by a gradual D-depletion to the present. Although changes in the mean position of the ITCZ during the AHP need not be symmetric about the meteorological equator, maximum D-enrichment in the Zambezi Fan ca 9 ka is compatible with peak early Holocene wet conditions and

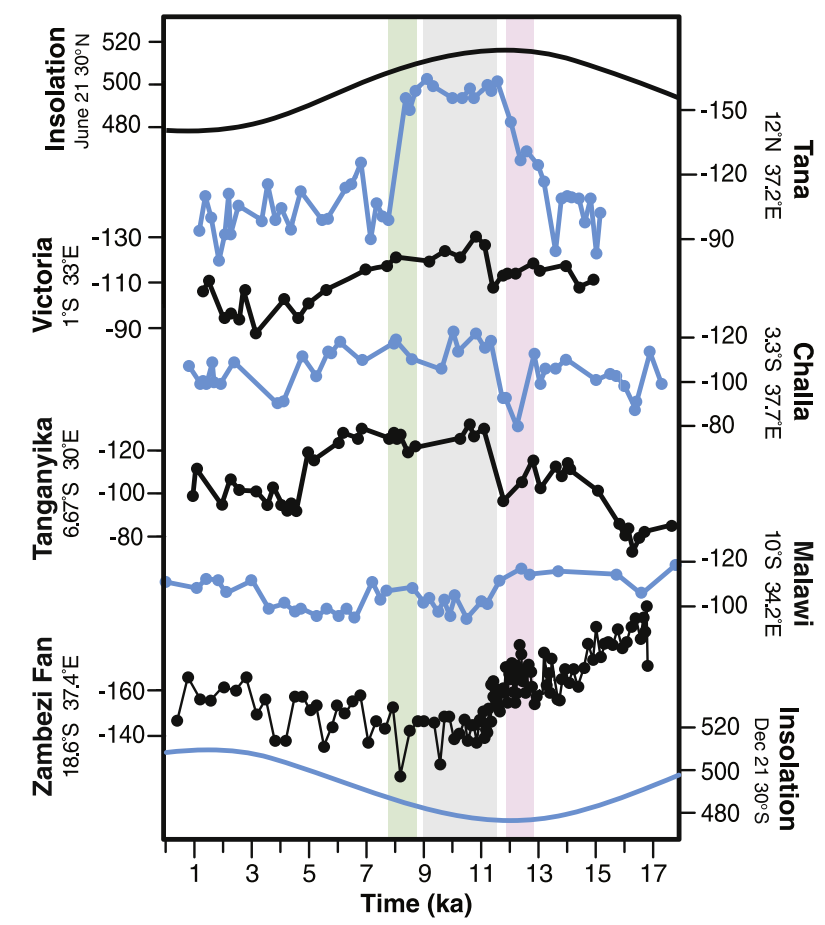

Fig. 4. $\delta D_{\text {wax }}(\%)$ records along a North-South transect of East Africa. Tana (this paper), Victoria (Berke et al., 2012), Challa (Tierney et al., 2010), Tanganyika (Tierney et al., 2008), Malawi (Konecky et al., 2011), Zambezi Fan (Schefuss et al., 2011). Gray bar indicates the peak of the AHP at Lake Tana. Pink bar indicates the Younger Dryas. Green bar indicates the 8.5 ka event. (For interpretation of the references to colour in this figure legend, the reader is referred to the web version of this article.) 
northward tropical rain belt migration observed at sites to the north, including Lake Tana.

Many records exhibit centennial- to millennial-scale events during the AHP, complicating the interpretation of the rate of its onset and termination throughout the region. The Younger Dryas (ca 12.5-11.8 ka), for instance, interrupts the transition from wet to dry conditions and from D-enriched to D-depleted waxes at many sites, possibly including Lake Tana. Furthermore, across much of East Africa, a brief D-enrichment at 8.5 ka interrupts an otherwise stable humid maximum. This D-enrichment event corresponds with aridification observed at many sites across tropical and subtropical Africa around 8.5-7.8 ka (Gasse, 2000) and may be linked to the 8.2 ka event observed in the GISP2 ice core and other sites globally (Alley et al., 1997). The $\delta D_{\text {wax }}$ signal of the $8.5 \mathrm{ka}$ event in Africa is highly variable and ranges from 5 to $10 \%$ (Tanganyika, Victoria, Challa) to $\sim 60 \%$ (Tana). At Lake Tana, this event appears to coincide with the transition from D-enriched to D-depleted waxes associated with the termination of the AHP, complicating the interpretation of the timing of the end of the AHP itself. However, we note that following this event the waxes are strongly Denriched at $7 \mathrm{ka}$ relative to the early Holocene average $\delta D_{\text {wax }}$ ( $-125 \%$ at 7 ka versus $-159 \%$ from 12 to $8 \mathrm{ka}$ ), implying an early and likely abrupt termination to the AHP depletion at Lake Tana.

While $\delta D_{\text {wax }}$ reconstructions thus suggest both strong similarities and significant differences in the nature of the AHP over East Africa, the potential for decoupling between rainfall amount and $\delta D_{\text {wax }}$ in East Africa complicates the interpretation of East African precipitation gradients based upon $\delta D_{\text {wax }}$ alone (Konecky et al., 2011; Tierney et al., 2011b). Comparison of our $\delta D_{\text {wax }}$ record with other paleohydrologic reconstructions from Ethiopia, including from Lake Tana, highlight this issue (Fig. 3). The interval of decreased $\delta D_{\text {wax }}$ from 13.5 to 8.5 ka corresponds to humid conditions as inferred from high sedimentary titanium concentrations (a proxy for surface runoff), lake level highstands at Lake Abhe and Lake Ziway-Shalla, low water salinities at Lake Abiyata, and low potassium concentrations (a proxy for aridity) at Chew Bahir (Gillespie et al., 1983; Gasse and Van Campo, 1994; Chalie and Gasse, 2002; Marshall et al., 2011; Foerster et al., 2012). However, we observe little change in $\delta D_{\text {wax }}$ at Lake Tana during the Younger Dryas, while low sedimentary titanium concentrations indicate drought, confirmed by a lake level lowstand at Lake Ziway-Shalla, high water salinities at Lake Abiyata, and high potassium concentrations at Chew Bahir (Gillespie et al., 1983; Chalie and Gasse, 2002; Marshall et al., 2011; Foerster et al., 2012). Many of these records also show a significant drought ca $8.5 \mathrm{ka}$, synchronous with increased $\delta D_{\text {wax }}$ in the new record presented here. However, following the 8.5 ka event, the waxes remain relatively D-enriched compared to the AHP, while sedimentary titanium concentrations at Lake Tana, lake level highstands at Lake Abhe and Lake Ziway-Shalla, low conductivity at Lake Abiyata, and low potassium concentrations at Chew Bahir support the continuation of humid conditions (Gillespie et al., 1983; Gasse and Van Campo, 1994; Chalie and Gasse, 2002; Marshall et al., 2011; Foerster et al., 2012). D-enriched waxes with coincident wet conditions indicate that the amount effect cannot be the only mechanism generating the decrease in $\delta D_{\text {wax }}$ during the AHP. The apparent discrepancy may instead reflect the influence of nonamount effects such as vapor source, transport distance, or other atmospheric processes on the $\delta D_{\text {wax }}$ at Lake Tana.

\subsection{Air mass back-trajectories}

The $\delta D$ of a parcel of water vapor depends on many factors, including where the vapor mass is sourced, how far it has traveled, how much vapor is lost as precipitation en route, and how much evaporated and transpired water it receives before reaching the precipitation location (Dansgaard, 1964; Rozanski et al., 1993). The three primary moisture sources for East Africa are the Indian Ocean, the Congo Basin (including Atlantic Ocean moisture recycled over the central African rainforests), and the Northern Seas (Mediterranean and Red) (Gimeno et al., 2010; Viste and Sorteberg, 2013). Air masses from the west must travel farther inland (stronger continental effect) to reach East Africa, and should therefore be Ddepleted relative to Indian Ocean sources. However, while traveling inland, these air masses cross the densely vegetated Congo basin, which transpires D-enriched vapor into overlying air masses (Rozanski et al., 1993; Frankenberg et al., 2009).

Changes in these moisture sources may strongly affect modern $\delta D_{\text {precip }}$ observed in Ethiopia (Levin et al., 2009). The rainy season in eastern Ethiopia occurs during boreal summer, when the CAB shifts and/or expands eastward and permits incursion of Congo Basin sourced air masses into the region (Nakamura, 1969; Hills, 1979; Davies et al., 1985). Previous studies have suggested that summer precipitation in Ethiopia is dominated by these D-enriched Congo Basin sourced air masses, resulting in anomalously high $\delta D_{\text {precip }}$ $(1.8 \%$ ) observed at Addis Ababa (Rozanski et al., 1993; Levin et al., 2009; Kebede and Travi, 2012). This inference is supported by recent observational studies that have shown that much of the precipitation falling over Ethiopia coincides with local westerly winds (Levin et al., 2009). However, the $\delta D_{\text {precip }}$ of Congo Basin sourced air masses is debated, as they have alternately been described as D-enriched (Joseph et al., 1992) and D-depleted (Tierney et al., 2011a). Satellite-derived observations of the $\delta D$ of water vapor from the SCIAMACHY platform (Frankenberg et al., 2009) indicate the prevalence of D-enriched vapor over the Congo basin, which suggests that the evapotranspiration effect dominates the $\delta D$ of Congo Basin-derived vapor (Fig. 5). However, interpolation of data from the Global Network of Isotopes in Precipitation (GNIP) stations suggest D-depleted precipitation in the Congo Basin (Tierney et al., 2011a), although no monitoring stations are currently present within the Congo Basin for confirmation. The mechanism fractionating the D-depleted precipitation from the Denriched water vapor is unknown, but could result at least partially from high rainfall amounts over the Congo. Implications for the $\delta D_{\text {precip }}$ from Congo Basin-derived air masses in East Africa remain similarly ambiguous.

To investigate the air masses that source Ethiopian precipitation and their effects on $\delta D_{\text {precip, }}$, we calculated 7-day air mass back trajectories using HYSPLIT (Draxler and Hess, 1998) for Lake Tana and Addis Ababa and compared them to seasonal precipitation isotopes recorded at Addis Ababa, the closest GNIP station for which robust rainfall isotope data are available. The air mass trajectories indicate that although almost all precipitation-bearing air masses approach the Lake Tana region from the west, the majority of these air masses are originally sourced from the Indian Ocean (Fig. 6). The Indian Ocean sourced 69-95\% (average 80\%) of the precipitation at Lake Tana, while the Congo Basin sourced 5-24\% (average 13\%) and the Northern Seas sourced 0-15\% (average 6\%) over the twelve-year analysis (2000-2011). Changes in the relative contribution of these sources are unrelated to the net annual precipitation amount (Fig. 7), but the relative source contribution does vary systematically on a monthly basis, as does $\delta D_{\text {precip }}$ at Addis Ababa (Fig. 8a). In an average year, the percentage of Congo Basin sourced precipitation at Addis Ababa increases from May to a peak in August before declining to negligible contributions in September through March, and a similar pattern is observed at Lake Tana (Fig. 8c). Importantly, $\delta D_{\text {precip }}$ at Addis Ababa varies little over the course of the year except in July and August, when the incursion of Congo Basin source air masses coincides with the period of the most D-depleted monthly precipitation ( $\delta D_{\text {precip }}=-2.8 \%$ ). Although July and August are also the months with highest 

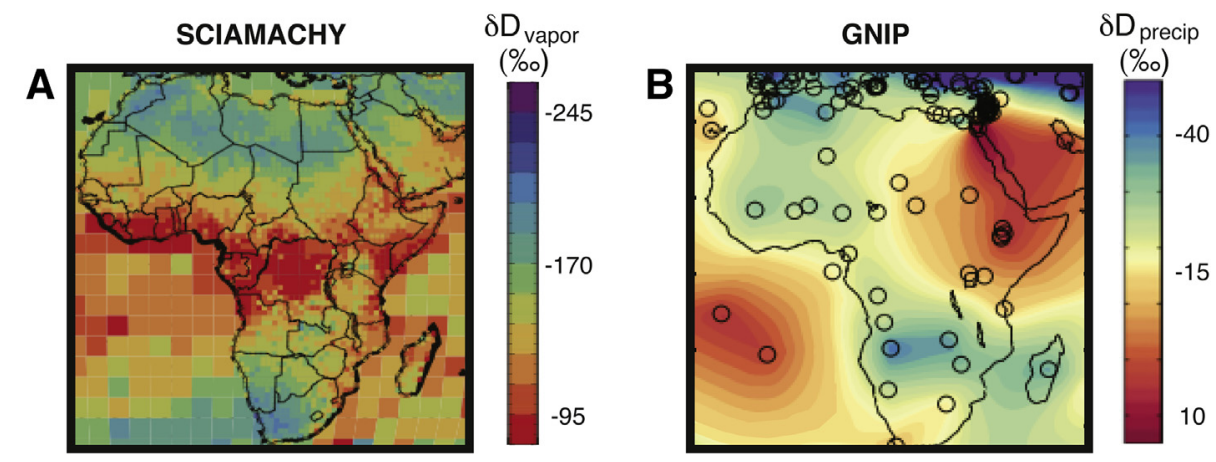

Fig. 5. A.) Annually averaged satellite based $\delta D_{\text {vapor }}$ observations from the SCIAMACHY platform (Frankenberg et al., 2009; Konecky et al., 2011). B.) Annual $\delta D_{\text {precip }}$ observed at GNIP stations (circles) (IAEA/WMO, 2013; Tierney et al., 2011a).

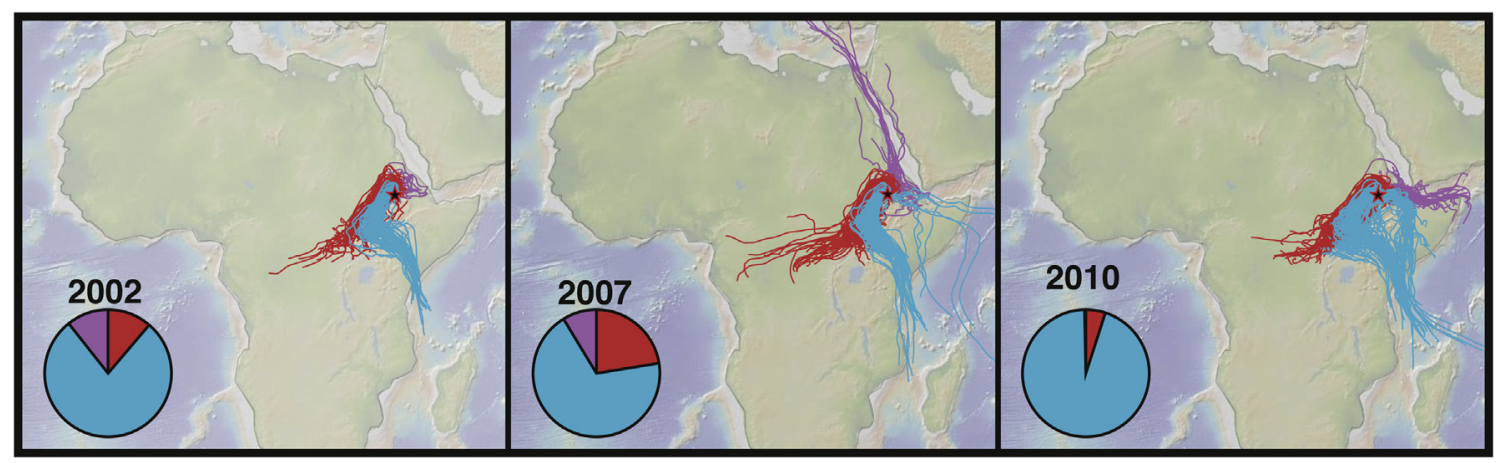

Fig. 6. Precipitation bearing air mass trajectories, compiled over the May-October rainy season for three contrasting years. Inset pie charts indicate the percentage of precipitation from each source: Indian Ocean (blue), Congo Basin (red), and Northern Seas (purple). 2002: High Northern Seas contribution to annual precipitation. 2007: High Congo Basin contribution to annual precipitation. 2010: Average source distribution of annual precipitation. (For interpretation of the references to colour in this figure legend, the reader is referred to the web version of this article.)

monthly precipitation, high precipitation in other months (e.g. June, September) does not result in similarly depleted precipitation. Rather, the relatively abundant rainfall during June and September, derived predominantly from Indian Ocean sources, has a $\delta D_{\text {precip }}$ equal to, or even slightly greater than, the annual mean at Addis Ababa. While multiple other processes might affect $\delta D_{\text {precip }}$ during the season, this analysis strongly suggests that incursions of Congo Basin sourced moisture bring D-depleted precipitation to the region.

Observational datasets of $\delta D_{\text {precip }}$ at Addis Ababa are relatively short and discontinuous at monthly timescales, complicating the

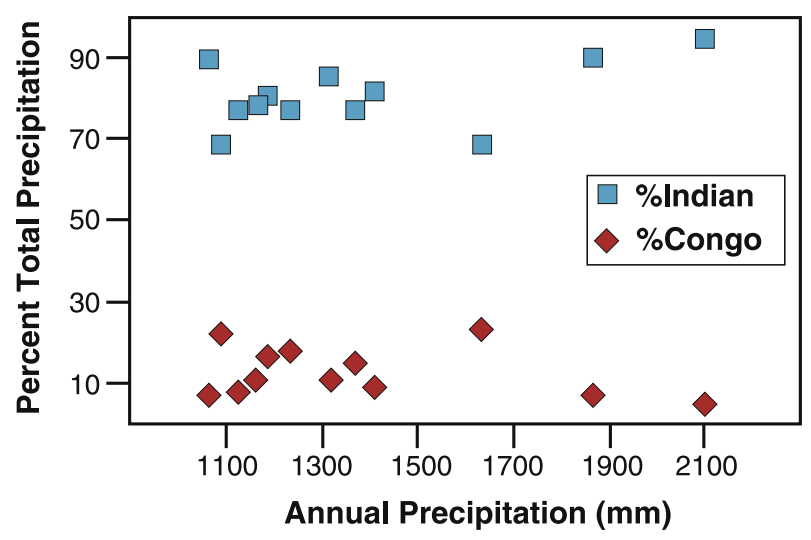

Fig. 7. Annual precipitation (May-October) for 2000-2011 at Lake Tana. The \%Congo derived precipitation and \%Indian derived precipitation show no dependence on the total amount of precipitation. analysis of the influence of moisture sources on annually integrated $\delta D_{\text {precip. }}$ Within the data that are available, observed monthly $\delta D_{\text {precip }}$ is significantly negatively correlated with both precipitation amount $\left(r^{2}=0.42, p<0.01\right)$ and \%Congo Basin sourced precipitation (\%Congo) $\left(r^{2}=0.38, p<0.01\right)$. We corrected $\delta D_{\text {precip }}$ for the amount effect, using linear regression, and found that the residual $\delta D_{\text {precip }}$ is still significantly correlated $\left(r^{2}=0.41\right.$, $p<0.01$ ) with \%Congo. The relationship between residual $\delta D_{\text {precip }}$ and \%Congo is strongest $\left(r^{2}=0.54\right)$ for July and August, consistent with the largest monthly contributions (30\%) from Congo Basin sources during those months. These data generally confirm our suggestions above that \%Congo is negatively correlated with $\delta D_{\text {precip. }}$

Some analyses of moisture sources in the Ethiopian highlands have suggested that the Northern Seas are a major source of water vapor for regional precipitation (Viste and Sorteberg, 2013), in contrast to our analysis of air mass trajectories at Lake Tana. As these studies use different meteorological datasets (ERA-Interim vs. NCEP Reanalysis), air mass trajectory models (FLEXPART vs HYSPLIT), trajectory lengths (15-20 days vs 7 days), target regions (Ethiopian Highlands, $8-14^{\circ} \mathrm{N}, 36-40^{\circ} \mathrm{E}$, vs Lake Tana, $12^{\circ} \mathrm{N}$ $37.25^{\circ} \mathrm{E}$ ), and precipitation estimation methods it is difficult to determine the source of these discrepancies. Despite these differences, all models indicate that the Congo Basin sourced precipitation peaks in July and August (Gimeno et al., 2010; Viste and Sorteberg, 2013), when the most D-depleted precipitation is observed at Addis Ababa. Changing the relative abundances of Northern and Indian sourced precipitation appears to have little impact on the observed $\delta D_{\text {precip }}$ (e.g., Fig. 8). In the context of past

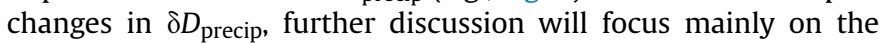




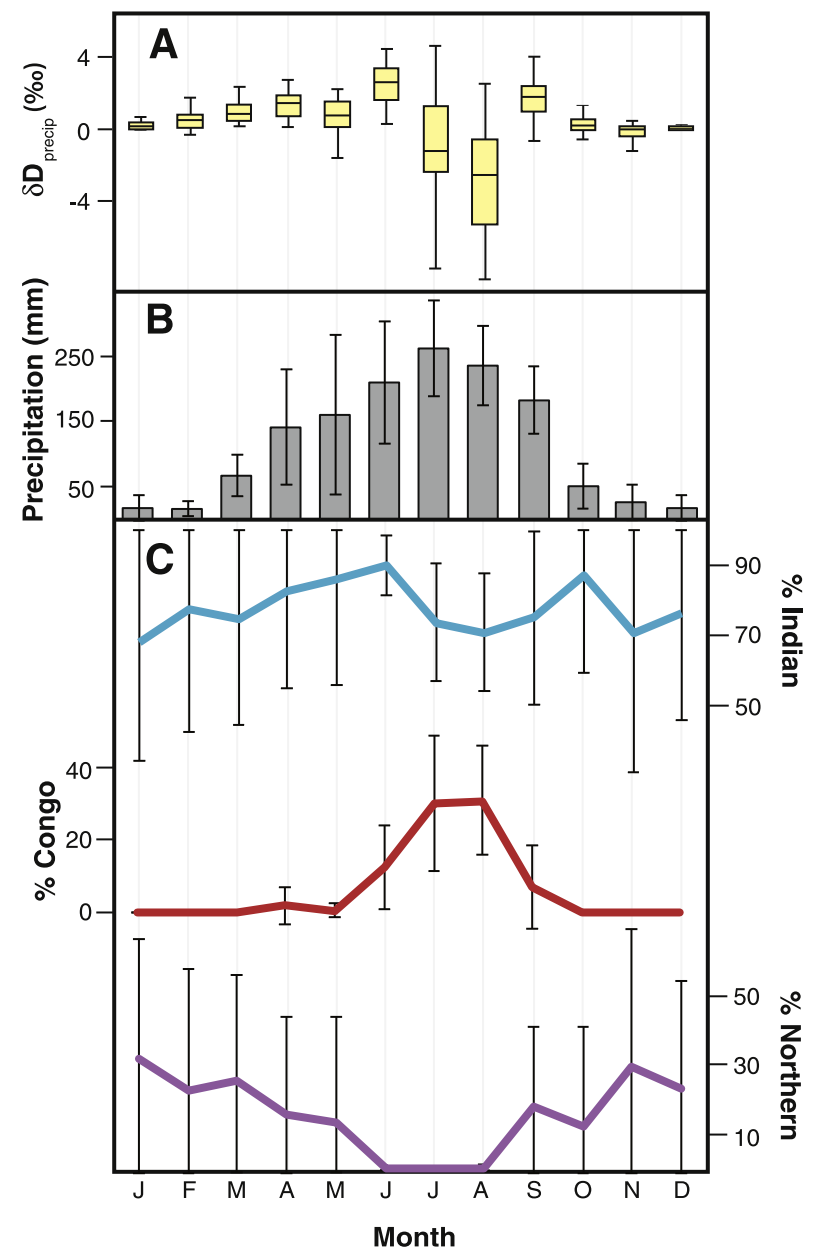

Fig. 8. A.) $\delta D_{\text {precip }}$ recorded at Addis Ababa (IAEA/WMO, 2013). B.) Annual variability in precipitation amount averaged over 12 years, 2000-2011, at Lake Tana. Error bars represent $1 \sigma$. C.) Annual precipitation source variability averaged over 12 years, 20002011 at Lake Tana. The Indian Ocean (blue) is the major precipitation source, while the Congo Basin sourced precipitation (red) peaks in July and August and the Northern Seas sourced precipitation (purple) peaks in January. Error bars represent $1 \sigma$. (For interpretation of the references to colour in this figure legend, the reader is referred to the web version of this article.)

effects of changes in \%Congo basin sourced precipitation as the Ddepleted endmember.

Assuming that precipitation from Congo Basin air masses in Ethiopia is relatively D-depleted compared to that from Indian Ocean and Northern Seas air masses (Fig. 8), the anomalously enriched annual $\delta D_{\text {precip }}$ observed in Ethiopia is most likely related to the dominance of Indian Ocean air masses. Other sites in East Africa proximal to Indian Ocean sources, such as Dar es Salaam, do not experience as extreme isotopic enrichment (Fig. 5b), suggesting that the enrichment observed in Ethiopia must be caused by the specific atmospheric history of air masses traveling over the region. Evaporation of falling raindrops in this relatively arid setting is one explanation (Dansgaard, 1964), but it would likely leave behind isotopically depleted water vapor, in contrast to what is observed in remotely sensed data (Fig. 5a). In the absence of other explanations, it seems likely that the isotopic compositions over Ethiopia during the boreal summer rainy season are indeed related to the first condensation of Indian Ocean-derived vapor carried into the region via the easterly jets, as first suggested by Joseph et al. (1992). Before encountering the Ethiopian highlands, these air masses travel over dry regions of East Africa that experience little precipitation during boreal summer. Therefore, these air masses are subject to little precipitative distillation and $\mathrm{D}$-depletion along their route from the Indian Ocean. This mechanism would also explain why air masses from the Northern Seas and the Indian Ocean would have similar $\delta D_{\text {precip }}$, as precipitation derived from (especially) the Red Sea is almost certain to represent the first condensation due to the short trajectory paths.

Given the presence of isotopically distinct moisture sources, changes in moisture source may contribute to $\delta D_{\text {wax }}$ variability at Lake Tana over long time-scales. The D-depleted waxes observed at Lake Tana during the early Holocene could result from increased rainout of Indian Ocean sourced air masses en route to Lake Tana (Worden et al., 2007). Indeed, many sites to the south and east of Lake Tana were wetter during the AHP (Gasse, 2000), an indication that rainfall was heavier along the trajectory of Indian Ocean sourced air masses. However, continued lake highstands at these sites after $8 \mathrm{ka}$, when waxes at Lake Tana become relatively Denriched (Fig. 3), indicates that the increased precipitation southeast of Lake Tana is not directly correlated to $\delta D_{\text {wax }}$ and does not seem to explain the large, amplified $\delta D$ response observed at Lake Tana during the AHP relative to other East African sites. Instead we suggest that increased Congo Basin contributions to annual precipitation may have contributed to the D-depleted waxes observed at Lake Tana from 8.5 to $13 \mathrm{ka}$.

\subsection{Atmospheric circulation over East Africa during the AHP}

Existing $\delta D_{\text {wax }}$ records from East Africa exhibit distinct spatial and temporal patterns associated with the onset and termination of the AHP. These differences reflect changes both in precipitation amount and in water vapor transport and convection over East Africa. Such circulation changes likely result not only from changes in precipitation rate and atmospheric convection, but also from shifts in the position of major convergence zones in the region, such as the tropical rain belt and the CAB (Nicholson, 1993; Levin et al., 2009; Tierney et al., 2011b). In the present seasonal cycle, the CAB migrates eastward as the tropical rain belt and ITCZ migrate northward, tracking increasing $\mathrm{NH}$ insolation during the boreal summer (Nakamura, 1969; Hills, 1979; Davies et al., 1985). This migration of the $C A B$ is linked with seasonal changes in the strength of the Indian monsoon (Camberlin, 1997), such that when increasing $\mathrm{NH}$ insolation strengthens the Indian monsoon during boreal summer, Indian Ocean air masses are drawn towards India and away from East Africa. Weakened penetration of Indian Ocean air masses into East Africa would perforce shift the convergence of Congo Basin and Indian Ocean air masses to the east. Whether and how the CAB migrates over orbital timescales is poorly constrained, but there is clear evidence for an intensified Indian monsoon during the early Holocene $\mathrm{NH}$ insolation maximum (e.g., Clemens et al., 1991; Fleitmann et al., 2003; Gupta et al., 2003; Kodera, 2004), which is consistent with an east-shifted $C A B$ at this time.

Changes in the relative contributions of Congo Basin and Indian Ocean sourced precipitation could be important sources of the $\delta D_{\text {wax }}$ decrease observed through much of equatorial East Africa during the AHP. In the modern, increasing the percent of Congo Basin (\%Congo) sourced precipitation from $0 \%$ in May to $30 \%$ in August corresponds to a $-4 \%$ change in $\delta D_{\text {precip }}$ (relative to the average annual $\delta D_{\text {precip }}$ ) at Addis Ababa (Rozanski et al., 1993). Extrapolating to the most extreme case, $100 \%$ Congo sourced precipitation would decrease $\delta D_{\text {precip }}$ by $14 \%$. By the source effect alone, this extreme scenario could account for about one quarter of the maximum $\delta D_{\text {wax }}$ signal observed at Lake Tana during the AHP $(60 \%)$. Although the isotopic composition of neither the Congo Basin nor the Indian Ocean sources can be assumed to be the same during the AHP as today, a more easterly CAB could play an important role in the significant isotopic depletion at Lake Tana. 
Thus, assuming that precipitation derived from Congo Basin sourced air masses during the early Holocene is also depleted relative to that from Indian Ocean sourced air masses, the observed depletion can best be interpreted as a combination of increased precipitation (amount effect) as well as increased \%Congo precipitation (source effect).

More broadly, changes in the position of the CAB may at least partially explain the regional asynchrony observed in the onset of the AHP over equatorial and eastern Africa (Fig. 9). During the initiation of the AHP in the Late Pleistocene, the decrease in $\delta D_{\text {wax }}$ is first recorded at $15 \mathrm{ka}$ at Tanganyika (Fig. 4), the westernmost site most proximal to an east-migrating $C A B$. Passage of the $C A B$ permitted the incursion of Congo Basin sourced air masses, which both increased precipitation (Tierney et al., 2011a) and decreased the $\delta D_{\text {precip. }}$. At Lake Tana, D-depletion could not commence until the $\mathrm{CAB}$ migrated farther east, apparently by $13 \mathrm{ka}$. Sites in between Tanganyika and Tana would be expected to show D-depletion beginning between 15 and $13 \mathrm{ka}$, mirroring the eastward migration of the CAB. The low resolution ( $\sim 500$ years), short length, and low amplitude of $\delta D_{\text {wax }}$ signal $(-30 \%$ ) at Victoria make it difficult to pinpoint the onset of AHP $\delta D_{\text {wax }}$ depletion (Berke et al., 2012). Records from other intermediate lakes (e.g., Turkana, Albert, Edward) may help substantiate the relationship between the CAB migration and the onset of humid conditions.

The variability in the amplitude of changes in $\delta D_{\text {wax }}$ during the AHP may also be linked to migration of the CAB. The amplitude is quantified as $\Delta \delta D_{\text {wax }}$, the change in $\delta D_{\text {wax }}$ between the indicated time, e.g., $10 \mathrm{ka}$, and the Late Holocene (LH, 5-0 ka) average $\left(\Delta \delta D_{\text {wax }}=\delta D_{\text {wax }}^{t}-\delta D_{\text {wax }}^{\mathrm{LH}}\right.$, where $t=$ indicated time). All sites reach their maximum amplitude change (enrichment at Malawi and Zambezi, depletion elsewhere) by about 10ka, but the magnitude of this change, $\Delta \delta D_{\text {wax }}$, varies from $-60 \%$ at Tana, to $-30 \%$ at Tanganyika and Victoria, to $-18 \%$ at Challa (Fig. 9). Because the $\Delta \delta D_{\text {wax }}$ is attributed to both increased precipitation and increased \% Congo, sites without Congo Basin sourced precipitation would be expected to have smaller $\Delta \delta D_{\text {wax. }}$. Challa is east of the CAB's present easternmost extent, and the $C A B$ is unlikely to have affected the lake as strongly as other sites during the AHP. Therefore its small $\Delta \delta D_{\text {wax }}$ value during the AHP $(-18 \%$ ) reflects the absence of increased \%Congo. Sites that currently receive some precipitation from the Congo Basin in the modern (Tanganyika, Victoria) show moderate $\Delta \delta D_{\text {wax }}(-30 \%)$, reflecting a relatively small change in $\%$ Congo (e.g., $50-60 \%$ ). Lake Tana, with the most extreme $\Delta \delta D_{\text {wax }}$

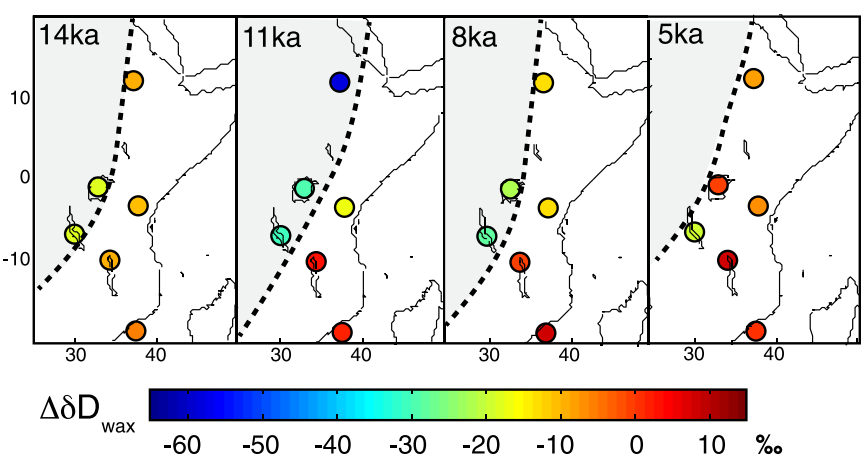

Fig. 9. Regional time slices of $\Delta \delta D_{\text {wax }}$ across East Africa during the AHP. The amplitude is quantified as $\Delta \delta D_{\text {wax }}$, the change in $\delta D_{\text {wax }}$ between the indicated time, e.g., $10 \mathrm{ka}$, and the Late Holocene (LH, 5-0 ka) average $\left(\Delta \delta D_{\text {wax }}=\delta D_{\text {wax }}^{\mathrm{t}}-\delta D_{\text {wax }}^{\mathrm{LH}}\right.$, where $t=$ indicated time). Negative $\Delta \delta D_{\text {wax }}$ reflects more D-depleted wax at the indicated time, while positive $\Delta \delta D_{\text {wax }}$ reflects more D-enriched wax at the indicated time. Dotted lines represent the CAB. Dotted line represents the CAB. Gray shading indicates the regions influenced by Congo Basin sourced precipitation. $\delta D_{\text {wax }}$ records from Tana (this paper), Victoria (Berke et al., 2012), Challa (Tierney et al., 2010), Tanganyika (Tierney et al., 2008), Malawi (Konecky et al., 2011), and Zambezi Fan (Schefuss et al., 2011).
$(-60 \%)$, by extension may have experienced the greatest change in \%Congo (e.g., 15-50\%).

Indeed, the abrupt and early termination of the AHP at Lake Tana may represent the loss of increased \%Congo due to the westward retreat of the CAB. Many proxies, including Ti-derived estimates of terrigenous runoff from Lake Tana, indicate reduced precipitation during the event and imply at least some of the D-enrichment can be explained by the amount effect. After the maximum enrichment ca 8.5 ka much of Ethiopia returned to humid conditions from 7 to $5 \mathrm{ka}$, as indicated by sedimentary titanium concentrations at Lake Tana and regional lake level records (Gillespie et al., 1983; Chalie and Gasse, 2002; Marshall et al., 2011). Lake Tana waxes do experience a minor D-depletion at $7 \mathrm{ka}$, but changes in $\delta D_{\text {wax }}$ still lead changes in sedimentary $\mathrm{Ti}$ and other hydrologic indicators. This result supports the hypothesis that the decrease in $\delta D_{\text {wax }}$ at Lake Tana is predominantly supported by changes in \%Congo, which is not directly correlated with changes in precipitation amount (e.g., as in Fig. 7). This also implies that the CAB began migrating westward while conditions remained wet in northern Ethiopia, with rainfall likely supported by Indian Ocean derived air masses from 7-5 ka.

\section{Conclusions}

We generate a new $\delta D_{\text {wax }}$ record from Lake Tana to investigate how the migration of the tropical rain belt and the $C A B$ impact the timing, duration, and intensity of the AHP over northeastern Africa. The long-term trend in $\delta D_{\text {wax }}$ at Lake Tana varies in relation to changes in Northern Hemisphere summer insolation, with the most D-depleted waxes at the time of maximum summer insolation (ca $11 \mathrm{ka}$ ). $\delta D_{\text {wax }}$ at Lake Tana is broadly similar to other regional $\delta D_{\text {wax }}$ records (Tierney et al., 2008; Konecky et al., 2011; Schefuss et al., 2011; Tierney et al., 2011b; Berke et al., 2012), but the local manifestations of the AHP appear highly variable in space and time. The apparent asynchrony of the AHP between sites in Eastern Africa, as recorded by $\delta D_{\text {wax }}$, reflects a time-transgressive change in atmospheric circulation that is consistent with northsouth migration of the mean tropical rain belt and east-west migration of the CAB in response to Northern Hemisphere summer insolation. Onset begins at Tanganyika (15 ka) and progresses eastward to Tana (13 ka). All sites reach their maximum amplitude change (enrichment at Malawi and Zambezi, depletion elsewhere) by about $10 \mathrm{ka}$, but the $\Delta \delta D_{\text {wax }}$ varies from $-60 \%$ at Tana, to $-30 \%$ at Tanganyika and Victoria, to $-18 \%$ at Challa relative to the average late Holocene value. This stable humid maximum is briefly interrupted at $8.5 \mathrm{ka}$, which represents the westward retreat of the CAB from Lake Tana. Gradual termination of the AHP aided by vegetation feedbacks appears to follow decreasing insolation until the abrupt aridification event at $4.5 \mathrm{ka}$.

The migration of the $\mathrm{CAB}$ and the incursion of Congo Basin sourced precipitation during the AHP can also explain the high $\Delta \delta D_{\text {wax }}$ (about twice that of Tanganyika) observed at Lake Tana. Analysis of air mass trajectories indicates that in the present the majority of the precipitation-bearing air masses at Lake Tana are ultimately sourced from the Indian Ocean. Averaging about 13\% of the annual total, Congo Basin sourced precipitation peaks in July and August, coinciding with the period of most depleted monthly $\delta D_{\text {precip }}(-2.8 \%$ ) recorded at Addis Ababa (Rozanski et al., 1993; Levin et al., 2009). Since increasing the \%Congo corresponds to $\delta D_{\text {precip }}$ depletion at Addis Ababa (Rozanski et al., 1993), a more easterly $\mathrm{CAB}$, permitting farther penetration of Congo Basin sourced air masses into East Africa, could clearly account for significant isotopic depletion at Lake Tana during the AHP. Humid conditions from 7-5 ka despite D-enriched waxes indicates that $\delta D_{\text {wax }}$ is decoupled from precipitation amount, and so we can infer 
that the anomalously high AHP $\Delta \delta D_{\text {wax }}$ at Lake Tana is predominantly a result of changes in \%Congo.

\section{Acknowledgments}

The authors thank Shannon Loomis for sampling assistance, Rafael Tarozo for technical support, and Phil Howell for HYSPLIT add-on software. We thank two anonymous reviewers for constructive feedback on this manuscript. This work was supported by NSF funding to J. Russell.

\section{References}

deMenocal, P.B., Ortiz, J., Guilderson, T., Sarnthein, M., 2000. Coherent high- and low-latitude climate variability during the Holocene Warm Period. Science 288, 2198-2202.

Adkins, J., deMenocal, P., Eshel, G., 2006. The "African humid period" and the record of marine upwelling from excess ${ }^{230} \mathrm{Th}$ in Ocean Drilling Program Hole 658C. Paleoceanography 21, PA4203.

Alley, R.B., Mayewski, P.A., Sowers, T., Stuiver, M., Taylor, K.C., Clark, P.U., 1997. Holocene climatic instability: a prominent, widespread event 8200 yr ago. Geology 25, 483-486.

Barker, P., Gasse, F., 2003. New evidence for a reduced water balance in East Africa during the Last Glacial Maximum: implication for model-data comparison. Quat. Sci. Rev. 22, 823-837.

Berke, M.A., Johnson, T.C., Werne, J.P., Grice, K., Schouten, S., Sinninghe Damsté, J.S., 2012. Molecular records of climate variability and vegetation response since the Late Pleistocene in the Lake Victoria basin, East Africa. Quat. Sci. Rev. 55, 59-74.

Broccoli, A.J., Dahl, K.A., Stouffer, R.J., 2006. Response of the ITCZ to northern hemisphere cooling. Geophys. Res. Lett. 33, 1-4.

Brooks, K., Scholz, C.A., King, J.W., Peck, J., Overpeck, J.T., Russell, J.M., Amoako, P.Y.O., 2005. Late-Quaternary lowstands of lake Bosumtwi, Ghana: evidence from high-resolution seismic-reflection and sediment-core data. Palaeogeogr. Palaeoclimatol. Palaeoecol. 216, 235-249.

Camberlin, P., 1997. Rainfall Anomalies in the source region of the Nile and their connection with the Indian summer monsoon. J. Clim. 10, 1380-1392.

Chalie, F., Gasse, F., 2002. Late Glacial-Holocene diatom record of water chemistry and lake level change from the tropical East African Rift Lake Abiyata (Ethiopia). Palaeogeogr. Palaeoclimatol. Palaeoecol. 187, 259-283.

Chase, B.M., Meadows, M.E., Scott, L., Thomas, D.S.G., Marais, E., Sealy, J., Reimer, P.J. 2009. A record of rapid Holocene climate change preserved in hyrax middens from southwestern Africa. Geology 37, 703-706.

Chikaraishi, Y., Naraoka, H., 2007. $\delta^{13} \mathrm{C}$ and $\delta D$ relationships among three n-alkyl compound classes (n-alkanoic acid, n-alkane and n-alkanol) of terrestrial higher plants. Org. Geochem. 38, 198-215.

Chikaraishi, Y., Naraoka, H., Poulson, S.R., 2004. Hydrogen and carbon isotopic fractionations of lipid biosynthesis among terrestrial (C3, C4 and CAM) and aquatic plants. Phytochemistry 65, 1369-1381.

Claussen, M., Kubatzki, C., Brovkin, V., Ganopolski, A., Hoelzmann, P., Pachur, H.-J. 1999. Simulation of an abrupt change in Saharan vegetation in the mid-Holocene. Geophys. Res. Lett. 26, 2037-2040.

Clemens, S.C., Prell, W., Murray, D.W., Shimmield, G., Weedon, G., 1991. Forcing mechanisms of the Indian Ocean monsoon. Nature 353, 720-725.

Dansgaard, W. 1964. Stable isotopes in precipitation. Tellus, 436-468.

Davies, T.D., Vincent, C.E., Beresford, A.K.C., 1985. July-August rainfall in WestCentral Kenya. J. Climatol. 5, 17-33.

Draxler, R.R., Hess, G.D., 1998. An overview of the HYSPLIT_4 modeling system of trajectories, dispersion, and deposition. Aust. Meteor. Mag. 47, 295-308.

Dykoski, C., Edwards, R., Cheng, H., Yuan, D., Cai, Y., Zhang, M., Lin, Y., Qing, J., An, Z Revenaugh, J., 2005. A high-resolution, absolute-dated Holocene and deglacia Asian monsoon record from Dongge Cave, China. Earth Planet. Sci. Lett. 233, $71-86$.

Fleitmann, D., Burns, S.J., Mudelsee, M., Neff, U., Kramers, J., Mangini, A., Matter, A 2003. Holocene forcing of the Indian monsoon recorded in a stalagmite from southern Oman. Science 300, 1737-1739.

Fleitmann, D., Burns, S.J., Mangini, A., Mudelsee, M., Kramers, J., Villa, I., Neff, U., AlSubbary, A.A., Buettner, A., Hippler, D., Matter, A., 2007. Holocene ITCZ and Indian monsoon dynamics recorded in stalagmites from Oman and Yemen (Socotra). Quat. Sci. Rev. 26, 170-188.

Foerster, V., Junginger, A., Langkamp, O., Gebru, T., Asrat, A., Umer, M., Lamb, H.F., Wennrich, V., Rethemeyer, J., Nowaczyk, N., Trauth, M.H., Schaebitz, F., 2012. Climatic change recorded in the sediments of the Chew Bahir basin, southern Ethiopia, during the last 45,000 years. Quat. Int. 274, 25-37.

Frankenberg, C., Yoshimura, K., Warneke, T., Aben, I., Butz, A., Deutscher, N. Griffith, D., Hase, F., Notholt, J., Schneider, M., Schrijver, H., Röckmann, T., 2009 Dynamic processes governing lower-tropospheric $\mathrm{HDO} / \mathrm{H}_{2} \mathrm{O}$ ratios as observed from space and ground. Science 325, 1374-1377.

Garcin, Y., Melnick, D., Strecker, M.R., Olago, D., Tiercelin, J.-J., 2012. East African mid-Holocene wet-dry transition recorded in palaeo-shorelines of Lake Turkana, northern Kenya Rift. Earth Planet. Sci. Lett. 331-332, 322-334.
Gasse, F., 2000. Hydrological changes in the African tropics since the Last Glacial Maximum. Quat. Sci. Rev. 19, 189-211.

Gasse, F., Van Campo, E., 1994. Abrupt post-glacial climate events in West Asia and North Africa monsoon domains. Earth Planet. Sci. Lett. 126, 435-456.

Gillespie, R., Street-Perrot, F., Switsur, R., 1983. Post-glacial arid episodes in Ethiopia have implications for climate prediction. Nature 306, 680-683.

Gimeno, L., Drumond, A., Nieto, R., Trigo, R.M., Stohl, A., 2010. On the origin of continental precipitation. Geophys. Res. Lett. 37.

Gupta, A.K., Anderson, D.M., Overpeck, J.T., 2003. Abrupt changes in the Asian southwest monsoon during the Holocene and their links to the North Atlantic Ocean. Nature 421, 354-357.

Haug, G.H., Hughen, K.A., Sigman, D.M., Peterson, L.C., Ro, U., 2001. Southward migration of the intertropical convergence zone through the Holocene. Science 293, 1304-1308.

Hély, C., Braconnot, P., Watrin, J., Zheng, W., 2009. Climate and vegetation: simulating the African humid period. Comptes Rendus Geosci. 341, 671-688.

Hills, R.C., 1979. The structure of the inter-tropical convergence zone in equatorial Africa and its relationship to East African rainfall. Trans. Inst. Brit. Geogr. 4, 329

Hou, J., D’Andrea, W.J., Huang, Y., 2008. Can sedimentary leaf waxes record D/H ratios of continental precipitation? Field, model, and experimental assessments Geochim. Cosmochim. Acta 72, 3503-3517.

Huang, Y., Shuman, B., Wang, Y., Webb III, T., 2004. Hydrogen isotope ratios of individual lipids in lake sediments as novel tracers of climatic and environmental change: a surface sediment test. J. Paleolimnol. 31, 363-375.

IAEA/WMO, 2013. Global Network of Isotopes in Precipitation. The GNIP Database. Accessible at: http://www.iaea.org/water.

Joseph, A., Frangi, J.P., Aranyossy, J.F., 1992. Isotope characteristics of meteoric water and groundwater in the Sahelo-Sudanese zone. J. Geophys. Res. 97, 7543-7551.

Jung, S.J.A., Davies, G.R., Ganssen, G.M., Kroon, D., 2004. Stepwise Holocene aridification in NE Africa deduced from dust-borne radiogenic isotope records. Earth Planet. Sci. Lett. 221, 27-37.

Kebede, S., Travi, Y., 2012. Origin of the $\delta^{18} \mathrm{O}$ and $\delta^{2} \mathrm{H}$ composition of meteoric waters in Ethiopia. Quat. Int. 257, 4-12.

Kodera, K., 2004. Solar influence on the Indian Ocean Monsoon through dynamica processes. Geophys. Res. Lett. 31.

Konecky, B.L., Russell, J.M., Johnson, T.C., Brown, E.T., Berke, M.A., Werne, J.P. Huang, Y., 2011. Atmospheric circulation patterns during late Pleistocene climate changes at Lake Malawi, Africa. Earth Planet. Sci. Lett. 312, 318-326.

Kröpelin, S., Verschuren, D., Lézine, A.-M., Eggermont, H., Cocquyt, C., Francus, P., Cazet, J.-P., Fagot, M., Rumes, B., Russell, J.M., Darius, F., Conley, D.J., Schuster, M., Von Suchodoletz, H., Engstrom, D.R., 2008. Climate-driven ecosystem succession in the Sahara: the past 6000 years. Science 320, 765-768.

Kuper, R., Kröpelin, S., 2006. Climate-controlled Holocene occupation in the Sahara: motor of Africa's evolution. Science (New York, N.Y.) 313, 803-807.

Lamb, H.F., Bates, C.R., Coombes, P.V., Marshall, M.H., Umer, M., Davies, S.J., Dejen, E. 2007. Late Pleistocene desiccation of Lake Tana, source of the Blue Nile. Quat Sci. Rev. 26, 287-299.

LeGrande, A.N., Schmidt, G.A., 2009. Sources of Holocene variability of oxygen isotopes in paleoclimate archives. Clim. Past Discuss. 5, 1133-1162.

Levin, N.E., Zipser, E.J., Cerling, T.E., 2009. Isotopic composition of waters from Ethiopia and Kenya: insights into moisture sources for eastern Africa. J. Geophys. Res. 114, D23306.

Liu, Z., Otto-Bliesner, B., Kutzbach, J., Li, L., Shields, C., 2003. Coupled climate simulation of the evolution of global monsoons in the Holocene. J. Clim. 16 , 2472-2490.

Liu, Z., Wang, Y., Gallimore, R., Gasse, F., Johnson, T., deMenocal, P., Adkins, J., Notaro, M., Prentice, I.C., Kutzbach, J., Jacob, R., Behling, P., Wang, L., Ong, E. 2007. Simulating the transient evolution and abrupt change of Northern Africa atmosphere-ocean-terrestrial ecosystem in the Holocene. Quate. Sci. Rev. 26, 1818-1837.

Marshall, M.H., Lamb, H.F., Huws, D., Davies, S.J., Bates, R., Bloemendal, J., Boyle, J. Leng, M.J., Umer, M., Bryant, C., 2011. Late Pleistocene and Holocene drought events at Lake Tana, the source of the Blue Nile. Glob. Planet. Chang. 78 $147-161$.

Nakamura, K., 1969. Equatorial westerlies over East Africa and their climatological significance. Jpn. Prog. Climatol., 9-27.

Nicholson, S.E., 1993. A review of climate dynamics and climate variability in eastern Africa. In: Swart, P.K., Lohmann, K.C., McKenzie, J., Savin, S. (Eds.) Climate Change in Continental Isotopic Records, Geophys. Monogr. Ser. AGU. D. C., Washington, pp. 25-56.

Nicholson, S., 2000. The nature of rainfall variability over Africa on time scales of decades to millenia. Glob. Planet. Change 26, 137-158.

Niedermeyer, E.M., Schefuß, E., Sessions, A.L., Mulitza, S., Mollenhauer, G. Schulz, M., Wefer, G., 2010. Orbital- and millennial-scale changes in the hydrologic cycle and vegetation in the western African Sahel: insights from individual plant wax $\delta D$ and $\delta^{13} C$. Quat. Sci. Rev. 29, 2996-3005.

Rozanski, K., Araguás-Araguás, L., Gonfiantini, R., 1993. Isotopic patterns in modern global precipitation. In: Swart, P.K., Lohmann, K.C., McKenzie, J., Savin, S. (Eds.) Climate Change in Continental Isotopic Records, Geophys. Monogr. Ser. AGU. D. C., Washington, pp. 79-93.

Sachse, D., Radke, J., Gleixner, G., 2004. Hydrogen isotope ratios of recent lacustrine sedimentary n-alkanes record modern climate variability. Geochim. Cosmochim. Acta 68, 4877-4889.

Sachse, D., Billault, I., Bowen, G.J., Chikaraishi, Y., Dawson, T.E., Feakins, S.J., Freeman, K.H., Magill, C.R., McInerney, F.A., Van der Meer, M.T.J., Polissar, P. 
Robins, R.J., Sachs, J.P., Schmidt, H.-L., Sessions, A.L., White, J.W.C., West, J.B., Kahmen, A., 2012. Molecular paleohydrology: interpreting the hydrogenisotopic composition of lipid biomarkers from photosynthesizing organisms. Ann. Rev. Earth Planet. Sci. 40, 221-249.

Schefuss, E., Kuhlmann, H., Mollenhauer, G., Prange, M., Pätzold, J., 2011. Forcing of wet phases in southeast Africa over the past 17,000 years. Nature 480, 509-512.

Shanahan, T.M., Overpeck, J.T., Wheeler, C.W., Beck, J.W., Pigati, J.S., Talbot, M.R., Scholz, C.A., Peck, J., King, J.W., 2006. Paleoclimatic variations in West Africa from a record of late Pleistocene and Holocene lake level stands of Lake Bosumtwi, Ghana. Palaeogeogr. Palaeoclimatol. Palaeoecol. 242, 287-302.

Smith, F.A., Freeman, K.H., 2006. Influence of physiology and climate on $\delta D$ of leaf wax n-alkanes from C3 and C4 grasses. Geochim. Cosmochim. Acta 70, $1172-1187$.

Tierney, J.E., Russell, J.M., Huang, Y., Damsté, J.S.S., Hopmans, E.C., Cohen, A.S., 2008. Northern hemisphere controls on tropical southeast African climate during the past 60,000 years. Science 322, 252-255.

Tierney, J.E., Russell, J.M., Huang, Y., 2010. A molecular perspective on Late Quaternary climate and vegetation change in the Lake Tanganyika basin, East Africa. Quat. Sci. Rev. 29, 787-800.
Tierney, J.E., Lewis, S.C., Cook, B.I., LeGrande, A.N., Schmidt, G.A., 2011a. Model, proxy and isotopic perspectives on the East African Humid Period. Earth Planet. Sci. Lett. 307, 103-112.

Tierney, J.E., Russell, J.M., Sinninghe Damsté, J.S., Huang, Y., Verschuren, D., 2011b. Late Quaternary behavior of the East African monsoon and the importance of the Congo Air Boundary. Quat. Sci. Rev. 30, 798-807.

Vijverberg, J., Sibbing, F.A., Dejen, E., 2009. Lake Tana: source of the Blue Nile. In: Dumont, H.J. (Ed.), The Nile: Origin, Environments, Limnology, and Human Use. Springer, Dordrecht, Netherlands, pp. 163-192.

Viste, E., Sorteberg, A., 2013. Moisture transport into the Ethiopian highlands. Int. J. Climatol. 33, 249-263.

Vuille, M., Werner, M., Bradley, R.S., Keimig, F., 2005. Stable isotopes in precipitation in the Asian monsoon region. J. Geophys. Res. 110, D23108.

Wang, Y.J., Cheng, H., Edwards, R.L., An, Z.S., Wu, J.Y., Shen, C.C., Dorale, J.A., 2001. A high-resolution absolute-dated late Pleistocene Monsoon record from Hulu Cave, China. Science 294, 2345-2348.

Worden, J., Noone, D., Bowman, K., Beer, R., Eldering, A., Fisher, B., Gunson, M., Goldman, A., Herman, R., Kulawik, S.S., Lampel, M., Osterman, G., Rinsland, C., Rodgers, C., Sander, S., Shephard, M., Webster, C.R., Worden, H., 2007. Importance of rain evaporation and continental convection in the tropical water cycle. Nature 445, 528-532. 